\title{
Retraction Note to: The Amsterdam Guild of Surgeons and the Training of Surgeons in the Early Modern Period
}

de Bree E, Schoretsanitis G

Department of Surgical Oncology, Medical School of Crete, University Hospital, Heraklion, Greece

Retraction NOTE:

Hellenic J Surg 2018;90:205-209

doi: $10.1007 / \mathrm{s} 13126-018-0471-1$

The editor -in-Chief has retracted this article [1]

because it significantly overlaps

with a previous published article

by Ijima et al in Dutch [2]
1. deBree, Schoretsanitis G. The Amsterdam Guild of Surgeons and the Training of the Surgeons in the Early Modern Period Hellenic J Surg 90, 205-209 2018.

https://doi.org/10.1007/s13126-018-0471-1

2. Frank F. A Ijpma, Robert Van de Graa, EGJM(Robert) Pierik en Thomas M. van Gulik, De meesterproef in de chirurginsopleidingEen historisch concept als voorbeedvoor nu? Nederlands Tijdschrift voor Genneskunde 1 (2010), on line: Ned TijschrGeneeskd2009; 153:A795

https://www.ntvg.nl/artikelen/de meesterproef-de-chirurgijnsopleiding/artikelinfo

The original article can be found online at https://www.ntvg.nl/artikelen/de meesterproefde-chirurgijnsopleiding/artikelinfo 